\title{
Development of a Hydrodynamic-Based Flood-Risk Management Tool for Assessing Redistribution of Expected Annual Damages in a Floodplain
}

\author{
Muhammad Atiq Ur Rehman Tariq 1,2®, Nitin Muttil ${ }^{1,2}{ }^{\mathbb{D}}$, Zohreh Rajabi ${ }^{1,2}$, Maha Hussein ${ }^{1}$ (D), \\ Muhammad Izhar Shah ${ }^{3}$, Muhammad Laiq Ur Rahman Shahid ${ }^{4}$, Shahana Janjua ${ }^{5}$, Rashid Farooq ${ }^{6}$ \\ and Anne W. M. Ng $7, * \mathbb{D}$ \\ check for \\ updates \\ Citation: Tariq, M.A.U.R.; Muttil, N.; \\ Rajabi, Z.; Hussein, M.; Shah, M.I.; \\ 1 College of Engineering and Science, Victoria University, Melbourne 8001, Australia; \\ Atiq.Tariq@yahoo.com (M.A.U.R.T.); Nitin.Muttil@vu.edu.au (N.M.); Zohreh.Rajabi@live.vu.edu.au (Z.R.); \\ Maha.Hussein@live.vu.edu.au (M.H.) \\ 2 Institute for Sustainable Industries \& Liveable Cities, Victoria University, P.O. Box 14428, \\ Melbourne 8001, Australia \\ 3 Department of Civil Engineering, COMSATS University Islamabad, Abbottabad Campus, \\ Abbottabad 22060, Pakistan; mizharshah@gmail.com \\ 4 Department of Electronic Engineering, University of Engineering and Technology Taxila, \\ Rawalpindi 46000, Pakistan; Laiq.Shahid@uettaxila.edu.pk \\ 5 School of Civil and Mechanical Engineering, Curtin University, Perth 6102, Australia; \\ s.janjua@postgrad.curtin.edu.au \\ 6 Department of Civil Engineering, International Islamic University, Islamabad 44000, Pakistan; \\ rashidmeo50@gmail.com \\ 7 College of Engineering, IT \& Environment, Charles Darwin University, Darwin, NT 0810, Australia \\ * Correspondence: Anne.Ng@cdu.edu.au
} Shahid, M.L.U.R.; Janjua, S.; Farooq, R.; Ng, A.W.M. Development of a Hydrodynamic-Based Flood-Risk Management Tool for Assessing Redistribution of Expected Annual Damages in a Floodplain. Water 2021, 13, 3562. https://doi.org/10.3390/ w13243562

Academic Editor: Pankaj Kumar

Received: 4 November 2021

Accepted: 10 December 2021

Published: 13 December 2021

Publisher's Note: MDPI stays neutral with regard to jurisdictional claims in published maps and institutional affiliations.

Copyright: (c) 2021 by the authors. Licensee MDPI, Basel, Switzerland. This article is an open access article distributed under the terms and conditions of the Creative Commons Attribution (CC BY) license (https:// creativecommons.org/licenses/by/ $4.0 /)$.
Abstract: Despite spending ample resources and procedural development in flood management, flood losses are still increasing worldwide. The losses caused by floods and costs incurred on management are two components of expected annual damages (EAD) due to floods. This study introduces a generalized approach for risk-based design where a range of probable floods are considered before and after a flood mitigation measure is implemented. The proposed approach is customized from the ISO Guide 31000 along with additional advantages of flood risk visualization. A Geographic Information System (GIS)-based design of a flood-protection dike is performed to exhibit the risk redistribution. The Chenab River is selected for the existing dike system. Detailed hazard behaviour and societal vulnerability are modelled and visualized for a range of all probable floods before and after the implementation of flood-protection dikes. EAD maps demonstrate the redistribution of induced and residual risks. It can be concluded that GIS-based EAD maps not only facilitate cost-effective solutions but also provide an accurate estimate of residual risks after the mitigation measures are applied. EAD maps also indicate the high-risk areas to facilitate designing secondary measures.

Keywords: flood hazard; flood risk; expected annual damages; residual risk; induced risk; GIS; risk redistribution

\section{Introduction}

The impact of floods occurs with a large variety throughout the world. To overcome this, many places have enforced flood-management and flood-mitigation measures to control floods and their negative impacts [1]. Flooding events not only affect underdeveloped nations but economically advanced and industrialized nations as well [2]. A tsunami that occurred in Japan in March 2011 is an example. Additionally, 90\% of all natural disasters in the USA are floods that cost about USD 6 billion annually [3-6]. The frequency of floods is expected to increase as a result of climate change in many places [7]. Lifestyle and 
demographic changes are the other causes in addition to climate change that trigger an increase in flood losses. At present, there seems no reduction despite spending ample recourses on structural and nonstructural measures [8].

A demand for more effective systems for flood management arises due to the high amount of flood losses occurring. Unfortunately, the establishment of effective and optimized strategies based on an accepted framework/standard is still an important issue [9] and if no serious step is taken now, the "disasters will continue to take people, communities, and governments by surprise" [10]. Although the purpose of all the criteria developed so far is weighing the benefits and costs of flood-mitigation measures, an increase in preciseness and reliability has been achieved with consistent improvements [11].

In-practice design criteria/assessment methods used for the design of flood measures can be divided into three broad categories: these include normative standards, probabilitybased designs, and risk-based assessment.

\subsection{Normative Design Criteria}

One of the first standards brought into practice is considered to be the normative criteria. The main reason for the use of this standard was to create a mutual understanding as well as set the minimum quality required. These standards have been obtained from experiments or past experiences which have been successful. Based on this approach, the minimum standards for the design of flood-protection structures must be met. For instance, the heights of flood-protection structures are designed against historical flood experienced [4,12], or, instead, as multiples of some rounded values, e.g., $5 \mathrm{ft}$, etc.

Although fewer analyses are required for these standards, these are not the best in terms of the cost to benefits ratio. In cases where high accuracy is not strictly required, these standards are still being used [13]. The Connecticut Resources Commission in the USA continued using one form of this standard till the late 1960s. About 5-7 times the mean annual flood level was considered as a standard [4]. In addition, the dikes in the Netherlands were built to the highest point of water level to avoid overtopping until 1953 [14].

\subsection{Probability-Based Standards}

As the knowledge of disaster management advanced, acceptance of the probabilistic safety standards received overwhelming response worldwide. The probability-based approach expresses the degree of flood-control by the return period of flood in years (N-years) [1]. With the probabilistic approach, future events can be predicted based on the extrapolation of past observations [15]. Currently, these safety standards are the most widely practiced methods for the design of flood-management plans.

Severe floods, higher than the design flood (surcharges), remain a black spot. A lack of ability to deal with severe floods has been experienced with these standards. A response to any severe flood would be a typical ad hoc reaction [16]. Another shortcoming of this method is that only the hazard probability is considered, irrespective of consequences, while the suitability of a measure should depend on the damages prevented [11]. Due to the probability-based nature of the standard, there is always some residual probability of failure left. However, similar to the normative standards, this method may cause ineffective use of valuable recourses, focusing on protection and ignoring the susceptibility of society [17]. Flood-management measures are not possible to be optimized using these standards.

\subsection{Risk-Based Assessment}

During the 1990s, risk-based assessment criteria were introduced in the field of flood management. The main difference with this method from the previous two is its focus on flood impacts rather than floods themselves. The risk-based assessment is focused on reducing all possible flood-related risks instead of considering the impacts of a specificdesign flood only [1]. Flood risk in a floodplain is defined as potential damages due to all possible floods. These damages cover economic, social, and/or environmental impacts. 
A fixed-return-period design flood not only ignores the surcharges, it underestimates the risk in a floodplain. Wobus et al. [18] found that the "expected annual damages" (EAD) is usually 5-7 times higher than the predicted damages from a 100-year flood event. Flood management can be optimized using the risk-based method.

\subsection{Research Philosophy and Objectives}

As every floodplain has its own hydrological, hydraulic, geophysical, environmental, and socioeconomic features, the design of any flood-protection measure based on a specified return-period flood cannot be justified. These parameters, along with discharge behaviour, must be carefully considered for the management of every individual floodplain. The second principle standing of this research is to investigate the role of all probable floods instead of focusing on a single design flood. This complies with the principle that "all floods must be managed and not just some" [1].

This article provides an illustration of the risk assessment for existing flood-protection dikes and presents how the visualization of flood-risk redistribution can be pivotal in overall flood-risk management. The proposed approach can be used for the design of structural and nonstructural measures. The procedure covers all damages caused by a range of probable flood scenarios with incremental probabilities. The risk maps are developed in a way to demonstrate the risk redistributions, considering the residual and induced risks.

\section{Literature Review}

There are different ways to determine flood risk, which makes it difficult to develop a generalized/standardized approach [19]. Diaconu et al. [19] compared the flood risk analysis methods and found that using hydraulic models are the most commonly used approach worldwide.

\subsection{Risk Redistribution in a Floodplain}

The design methods currently practiced are unable to cover the post-flooding response of a floodplain or are unable to detail the redistribution of flood risk within a floodplain. An ideal designing process for a flood measure should be capable of quantifying the reduction in flood losses while considering the induced risk expected to be caused by the measure itself as well as the residual risk [20].

\subsubsection{Residual Risk}

It has been realized that it is almost impossible for a risk to be completely eliminated $[16,21,22]$. No matter the actions taken to prevent a flood, there will always be some kind of "residual risk" [23]. It is defined as a risk that remains even after flood measures have been taken [24]. As a result, the desire for full protection at the time of a few decades ago has now been changed to a risk-based sustainable floodplain-management concept [2] The risk behind dikes or downstream dams is usually ignored and not accounted for in land-use planning. The consequences and management of more severe floods than the anticipated design flood must be taken into consideration [16].

The flood-risk analyses are more complex in urban areas than in rural. This is due to the proximity to the built environment, type of land use, number of flood-control works, and drainage systems that may cause residual risk even after some measures are applied [25]. Most causes of residual risk are due to design assumptions and lack of knowledge. For instance, the chances of a structural failure against floods are lower than the design flood [26], or for many reasons, hydrological circumstances in the catchment may change over time [1] or the risk is induced by the measures themselves [27,28]. A portion of this residual risk is related to induced flood risk that occurs due to modified floodplain conditions, whereas the risk that still exists consists of the cost incurred on flood measures and residual flood damage, as shown in Figure 1. 


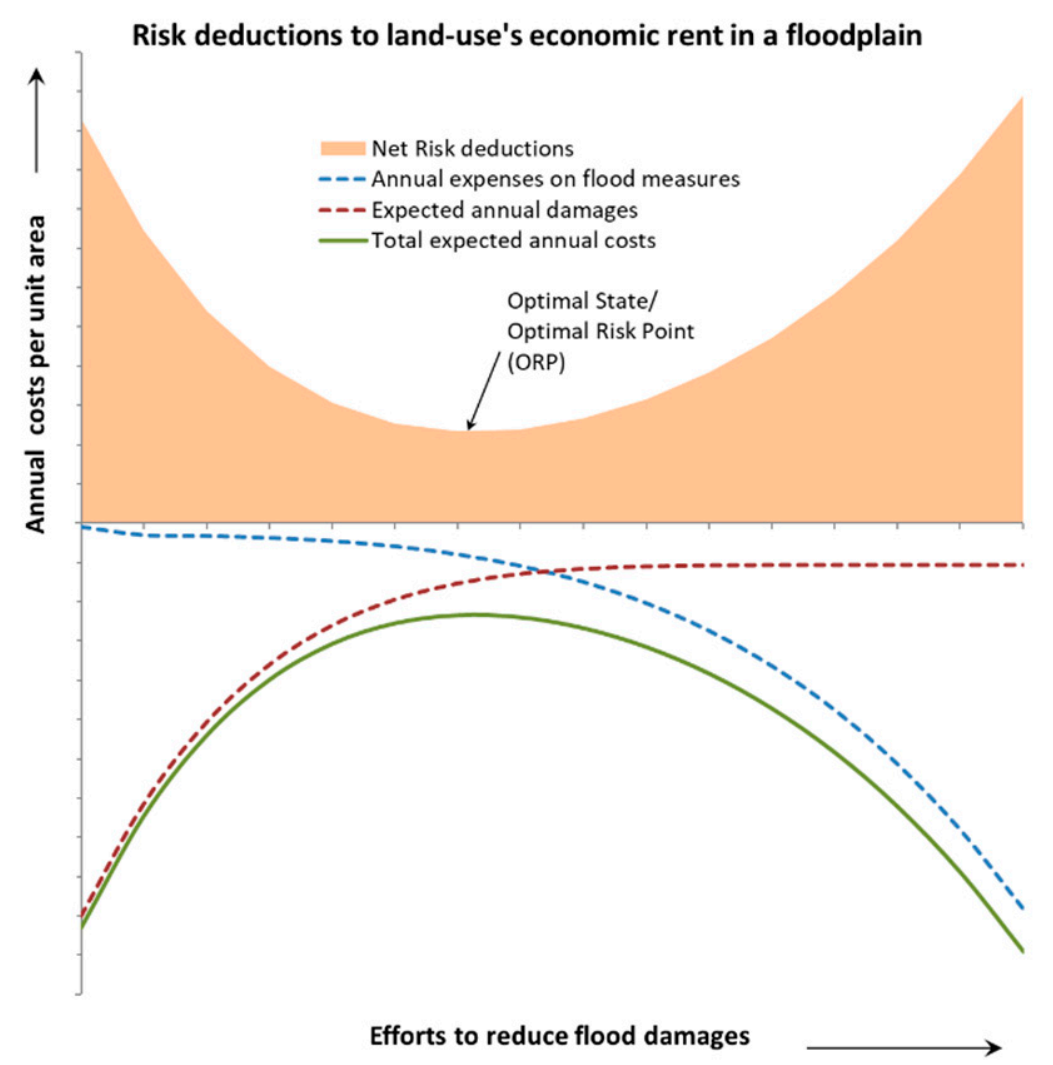

Figure 1. Combined flood deductions due to flood losses and costs on measures.

\subsubsection{Induced Risk}

The structural measures cause alteration to the floodplain that results in large-scale modifications to flow regimes. Most of these measures limit the flood spread or divert peak flow. This persuades the flood-risk areas on the opposite bank, upstream, or occasionally downstream areas. These also sometimes cause increased localized higher flood levels [29]. So far, the shifting of risks to other areas has often been ignored during the design process $[6,30]$. Another type of induced risk is caused by the increase in flood intensity when structural measures fail, such as dikes, dams, etc. In a recent case study, Pinter et al. [29] found that the dikes which are securing USD 51 million annually are also producing $11 \%$ induced negative impacts due to increased flood levels and pooling effects of overtopped floods.

\subsubsection{Floodplain Dynamics}

Drains and rivers keep on morphing their regimes based on the flow conditions and sediment loads over timescales [31]. Almost all structural measures accelerate this process, but by shifting the flood risk to upstream/downstream/or even across the bank. In addition to shifting of risk, the river flow pattern is also disturbed, which produces concentrated stresses on the river regime and cannot be ignored during the flood-measure design. Hydrodynamic models can analyse the shifts, predict the morphology, and incorporate the floodplain modifications. With advancement, 2D models are producing better visualization of flooding behaviour [32]. Such visualization of floods show the performance of various parameters results in flood maps or flood-risk maps $[33,34]$. These risk maps can be utilized as a base for the design of structural and nonstructural flood management measures.

\subsubsection{Socioeconomic Development}

Socioeconomic development in a floodplain, and the level of flood management support each other. A floodplain without any socioeconomic exposure does not need flood management, and a floodplain that has an effective flood management in place is 
more attractive for socioeconomic activities. Similarly, flood management in a developed floodplain is inevitable due to public expectations and demand for protection measures. As a result, flood-protection measures are installed in urbanized floodplains. However, more severe flood events cause catastrophes which are followed by public demand for higher protection from flood [35]. These demands and more followed-up protection measures result in a "diking cycle" [36]. This turn-by-turn increment in safety level supports and adds exposure gradually in a floodplain as floodplain inhabitants feel more secure and invest further in economic activities within a floodplain [37]. On a theoretical basis, this diking cycle has no end, but very high dikes are avoided, and alternative options are adopted eventually [38]. A dike failure in a floodplain results in more devastation than if there were no dike, primarily because of more severe and sudden flooding followed by the pooling effect of dikes, and secondly because of increased exposure and susceptibility of floodplain inhabitants being unprepared for the risk [36,39].

The prevailing design standards sometimes lose their economic effectiveness for considering a fixed design flood. Designing for higher safety levels results in uneconomical designs that involve higher construction and maintenance costs of hydraulic structures [30]. The risk-based design works on the principle of investing in flood-management structures that are within the socioeconomic affordability limits of a floodplain.

\subsection{Expected Annual Damages}

Floods and flood damages are considered probabilistic events [40]. In the same way, flood intensity and societal vulnerability vary greatly over the floodplain. EAD refers to the average damages expected annually due to floods and flood losses. The calculation of EAD due to flooding is a "strong indicator" as it allows users to see just how vulnerable the area is to flood risk [41].

The relationship between the damage, frequency, discharge, and stage was used by the US Army Corps of Engineers in the 1990s to develop a hydroeconomic model which estimated the EAD [40]. These correlations work well, considering flow conditions and societal vulnerabilities remained undisturbed. Significant changes in the flow regime and flood behaviour are caused by the floodplain infrastructure developments as well as by implementing structural measures, which alter the previously developed relationships. Therefore, a hydroeconomic model does not apply to modified floodplains.

A straightforward way to calculate EAD is to add up a time series of annual damages and divide by the number of years. However, it becomes difficult to use this method as most of the years will have a value of zero. It is, therefore, advisable to calculate EAD by first fitting a frequency distribution of various flood magnitudes. As there are slight differences in methods to calculate EAD, it is noticed, however, that the method is of "minor importance", but rather the importance is in the "shift from the damage as a function of the return period" [41].

\section{Method and Analysis}

For the analysis purposes, the theoretical level of risk that exists in a floodplain in the absence of any flood-management measure can be considered as "baseline" [42]. The increased socioeconomic activities are also an induced risk that has emerged due to higher safety standards in a floodplain. Defining a baseline is important for the performance analysis of proposed flood-management measures as a reference point.

Probabilistic standards are defined with a country's socioeconomic conditions, which do not state geophysical, social, and economic alternatives for floodplains. Additionally, these standards deem the probability of floods regardless of societal vulnerability. All floodplains possess unique characteristics and therefore should be treated suitably. Single design floods are used to estimate the flood damage, and the reaction of systems against additional possible floods is overlooked. This causes an additional problem as an incomplete analysis mistreats both residual and induced risk, which are more extremely important. 
Risk-based design is a rationale, in fact, to reduce the risk by implementing the measures. According to ISO Guide 31000, risk management must have the components of context establishment, risk factor identification, risk analysis, risk evaluation, and risk treatment. This process should be in consultation with stakeholders and must be monitored on a regular basis. Figure 2 shows the customized risk assessment approach for flood-risk management.

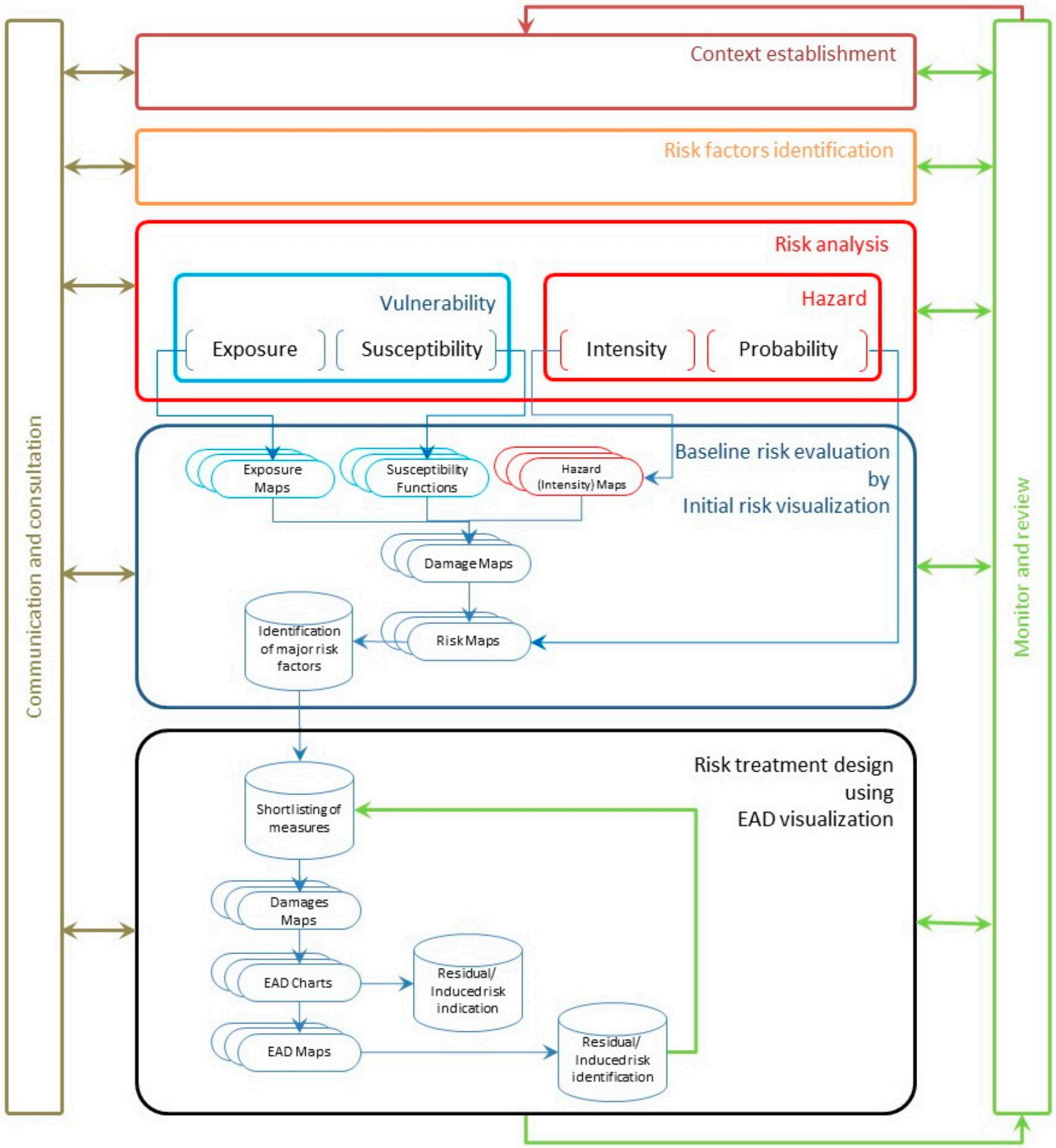

Figure 2. Proposed methodology aligned with ISO Guide 31000; this study elaborates the last two parts of the framework regarding the risk visualization of baseline and EAD visualization [43]. 
The proposed method has been established on expected annual damages. The following sections elaborate on the details of the methodology.

\subsection{Risk Context and Factors}

The first step towards risk-based design is to understand the risk context and process, as well as hazard and vulnerability factors (refer to Figure 2). For flood-risk management, these risk factors include the factors at catchment, river, and floodplain, as shown in Figure 3 in detail. These factors trigger the flood hazard. For risk analysis, the main components of exposure, susceptibility, and intensity of hazard are also explained in the same figure.

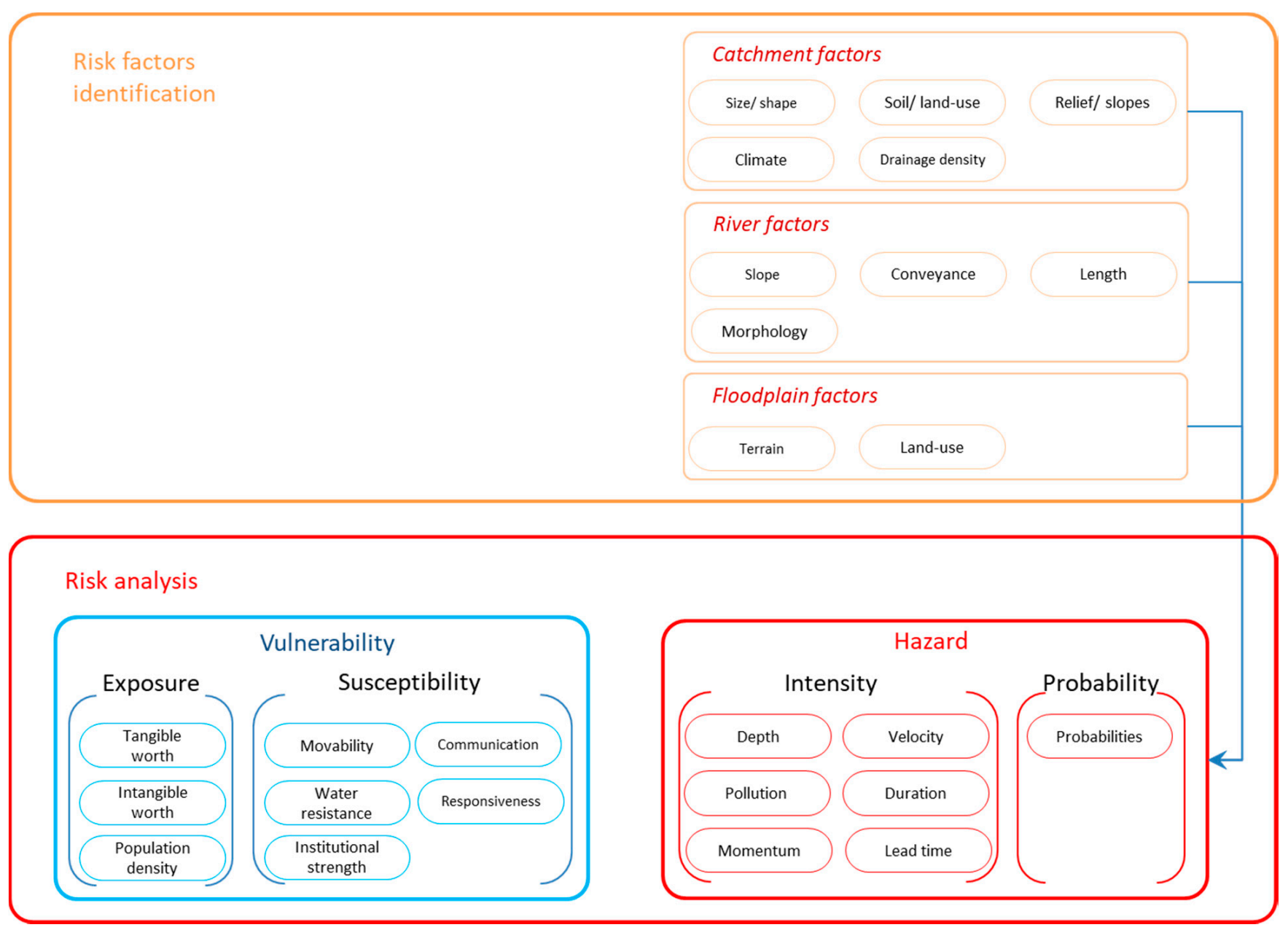

Figure 3. Detailed breakdown of risk factors and their role in risk analysis.

\subsection{Risk Analysis}

Risk can be conceived as "an estimate of potential consequences associated with a hazard" (Equation (1)), whereas the risk mechanics can be defined as a mutual interaction of hazard and vulnerability (Equation (2)) [25,44-48].

$$
\begin{gathered}
\text { Risk }=\text { Probability } \times \text { Consequences } \\
\text { Risk }=\text { Hazard } \times \text { Vulnerability }
\end{gathered}
$$

Hazard is characterized by probability and intensity, whereas vulnerability consists of exposure and susceptibility [49-51]:

$$
\text { Hazard }=\text { Probability }(\mathrm{P}) \times \text { Intensity }(\mathrm{I})
$$




$$
\text { Vulnerability }=\text { Susceptibility }(S) \times \text { Exposure }(E)
$$

"Probability" is the chance of a flood to occur within a timeframe. The flood is characterized by its intensity, which is different at different locations within the floodplain. The probability is sometimes expressed with the time period (inverse of frequency) known as the return period for a better visualization [52], whereas the intensity is the quality of the hazard that causes the negative impacts (consequences).

"Susceptibility" is the damage function of the subjects exposed to a hazard [53,54], while the exposure can be expressed in tangible or intangible terms to express the extent of valuables that may be damaged from a hazard [55]. Now, the expression can be expressed comprehensively by substituting the hazard and vulnerability factors in Equation (2).

$$
\text { Risk }=\mathrm{P} \times \mathrm{I} \times \mathrm{S} \times \mathrm{E}
$$

Probability has no units, whereas the flood intensity can be expressed by a single or a combination of their characteristics, e.g., flood depth will have meter as unit. Susceptibility is expressed in inverse units as those of intensity. Risk and exposure are expressed in the same units, normally in monitory terms. Considering the hazards and vulnerability factors of floodplains, available data, and suitability to our research project, the Chenab River in Pakistan was selected as the study area.

\subsection{Initial Risk Visualization}

Following the procedure described in Figure 2, the initial task is to evaluate the flood risk for the baseline case without any flood mitigation measure.

\subsubsection{Exposure Map of the Study Area}

The research project covers the fluvial floodplains in Pakistan. The Chenab River is proven, so far, to be the most devastating. The river has a total length of $1240 \mathrm{~km}$ and drains a $67,500 \mathrm{~km}^{2}$ catchment area. This catchment area excludes its major tributaries such as Jhelum, Ravi, and Satluj. The river drains into the Indus River near Uch Sharif [56]. There is no storage site within Pakistan and the flood warning is not effective due to a lack of effective communication between an upper and a lower riparian. Although the Baghlayar and Salal hydropower dams in India have a minor effect on flood mitigation due to the limited storage and lack of reservoir operation practices, higher floods are expected in the future due to deforestation in upstream catchments [57].

Marala Headworks is the first structure on the river after Munawanaerwali Tawi and Tawi River join the Chenab River in Pakistan. A $42 \mathrm{~km}$ long reach from Marala Headworks to Alexandria Bridge is selected for the flood-risk management study. Remote sensing has been a significant and effective technique in flood mapping and management $[58,59]$. The Pakistan Survey Department maps are used to develop the land-use maps (exposure maps as referred to in Figure 2), which are also calibrated with Google Maps and ground trothing techniques (refer to Figure 4). The floodplain mainly consists of clay soil with low infiltration. However, infiltration is not considered in flood simulations.

\subsubsection{Probability Analysis}

Flood risk refers to the functions of damages and their probabilities. Both flood occurrence and losses are considered probabilistic. Frequency analysis is used to estimate the probability of a flood occurring, whereas intensity-damage functions are used to treat the probability of losses occurring. A straightforward method for estimating flood probabilities is by using frequency analysis, which includes fitting annual peak-flows to the closely matched cumulative probability distribution function [60]. Frequency analysis is performed on the study area to estimate the probability of potential peak discharge. To perform a frequency analysis, the software "Design Flood" was used [61]. About 83 years of annual peak-flow data was used for the statistical analysis. Collected data followed 
the log-Pearson type III distribution, which is calculated with the method of moments, as shown in Figure 5.

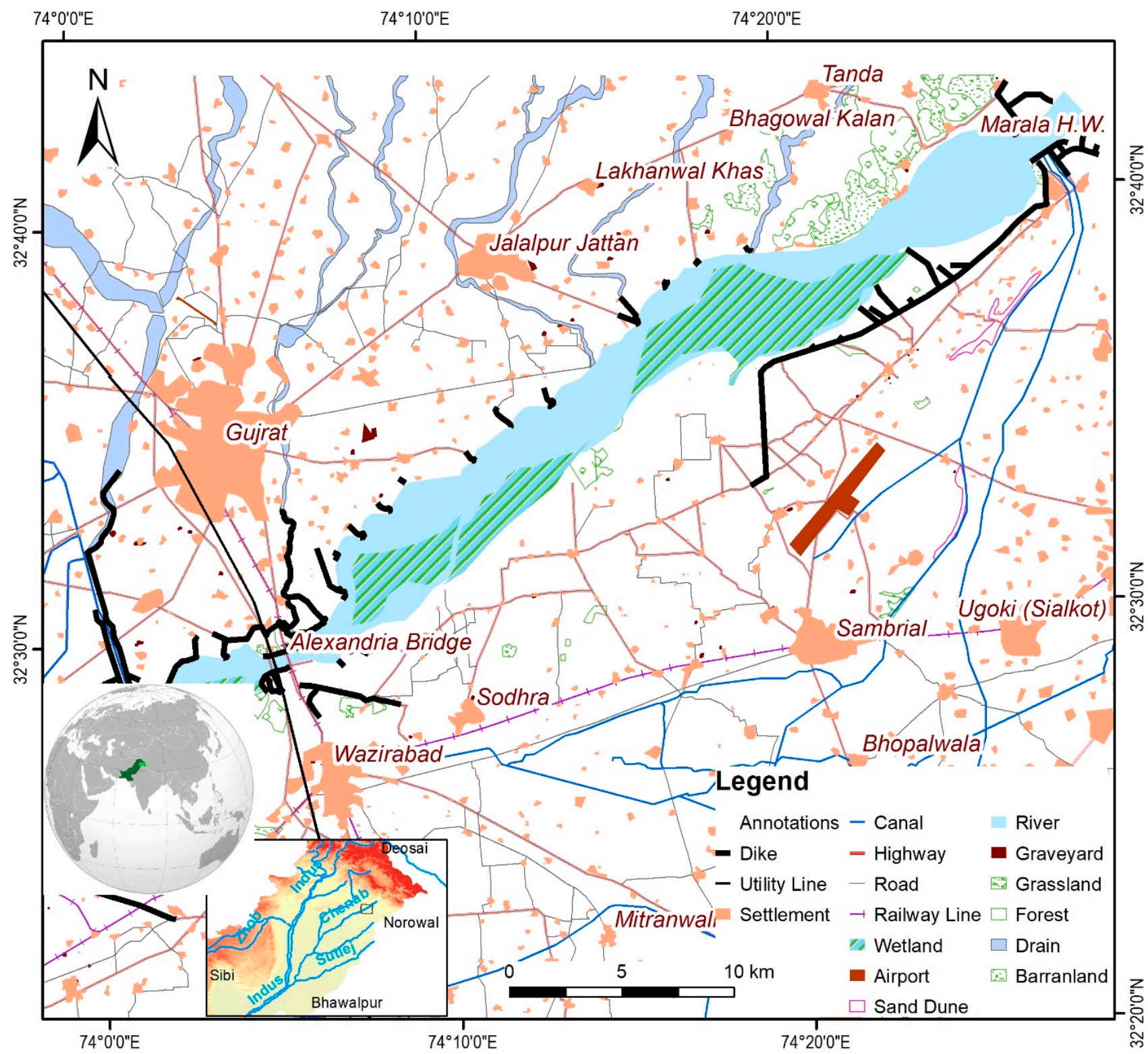

Figure 4. Study area digitized from Marala Headworks to Alexandria Bridge, a $42 \mathrm{~km}$ long reach of the Chenab River, Pakistan to represent the exposure map.

Log-Pearson type III distribution was chosen based on its goodness of fit using chi square values when dividing the population data into 10 classes, as well as the graphical/visual fit where the cumulative distribution was fitting more precisely and closely compared to other distributions (refer to Figure 5).

\subsubsection{Flood-Intensity Maps}

It is required to model the behaviour of a flood hazard when designing a flood measure [1]. The Sobek Rural "1D-2D" module, with a 90 m resolution DEM attained from HydroSHED, was used to simulate flood depths and floodplain areas [62]. Selected frequencies were used to run the model for a range of probable floods. With the use of HEC RAS, HEC GeoRAS, and Sobek "1D-2D Rural" software packages, a schematic layout of the model and hydraulic simulation was performed. The Sobek Rural "1D-2D" module basically works on Saint Venant equations to perform transit flow phenomenon 
and backwater profiling. The software has the flexibility to define asymmetrical cross sections as well as the interpolated subsections. Using mass conservation, the software can flood and dry the floodplain in 1D/2D simulations. It can also deal with steep channels exhibiting supercritical flows [63].

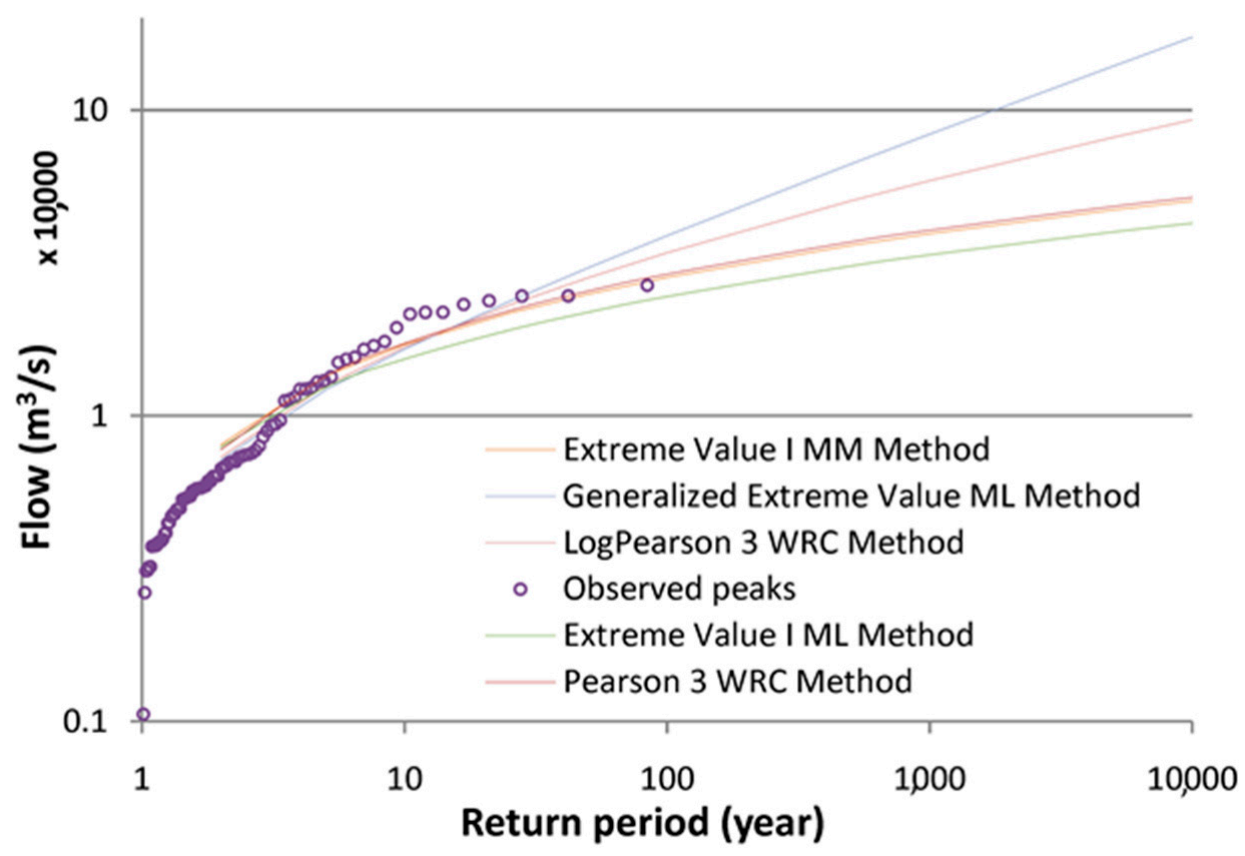

Figure 5. Flood-frequency analysis for the Chenab River at Marala Headworks using log-Pearson type III distribution (MM method).

According to the data availability, the model of Chenab River was calibrated carefully and validated against the water levels recorded at Marala Headworks and Alexandria Bridge. Model parameter performance plots for both sections are provided in Appendix A. The initial values of Manning's roughness coefficient " $n$ " were chosen from the literature review by Chow [64]. In addition to the recorded flood levels at Marala and Alexandria, the flood spreads were calibrated with flood maps developed by NESPak [65].

Figure 6 represents ten different flood flows ranging in probabilities from 0.0001 to 0.5 , which also include flood probabilities for $0.0002,0.001,0.002,0.01,0.02,0.04,0.1$, and 0.2. The central figure section shows the accumulation of all probable depths of expected annual floods.

\subsubsection{Susceptibility Functions}

For the damage estimation purpose, only tangible economic exposure was considered. Damage estimation covers both the economic and engineering aspects and can be performed using various methods [66]. Selecting the appropriate technique depends on a variety of factors, not just the data availability. However, some commonly accepted techniques exist for loss estimation. For small-scale studies, the "yardstick approach" is an effective technique. It is also known as the "unit loss model". Individual properties are considered for this approach to calculate the damage per unit area [53]. Information about land use is required. The process works by calculating the reduction in land-use cost affected by the intensity of flood (most commonly, flood depth is used). Percentages of potential damages are used to calculate the flood damages, whereas the relationship between flood intensity parameters and land-use susceptibility is used to calculate the percentage. Usually, an accepted standard method to measure direct flood damages is called a "stage-damage function" [66-68]. The same standard is used in our research. Calculation of casualties and population at risk can also be used with this strategy; however, this is not covered in our studies [36]. 


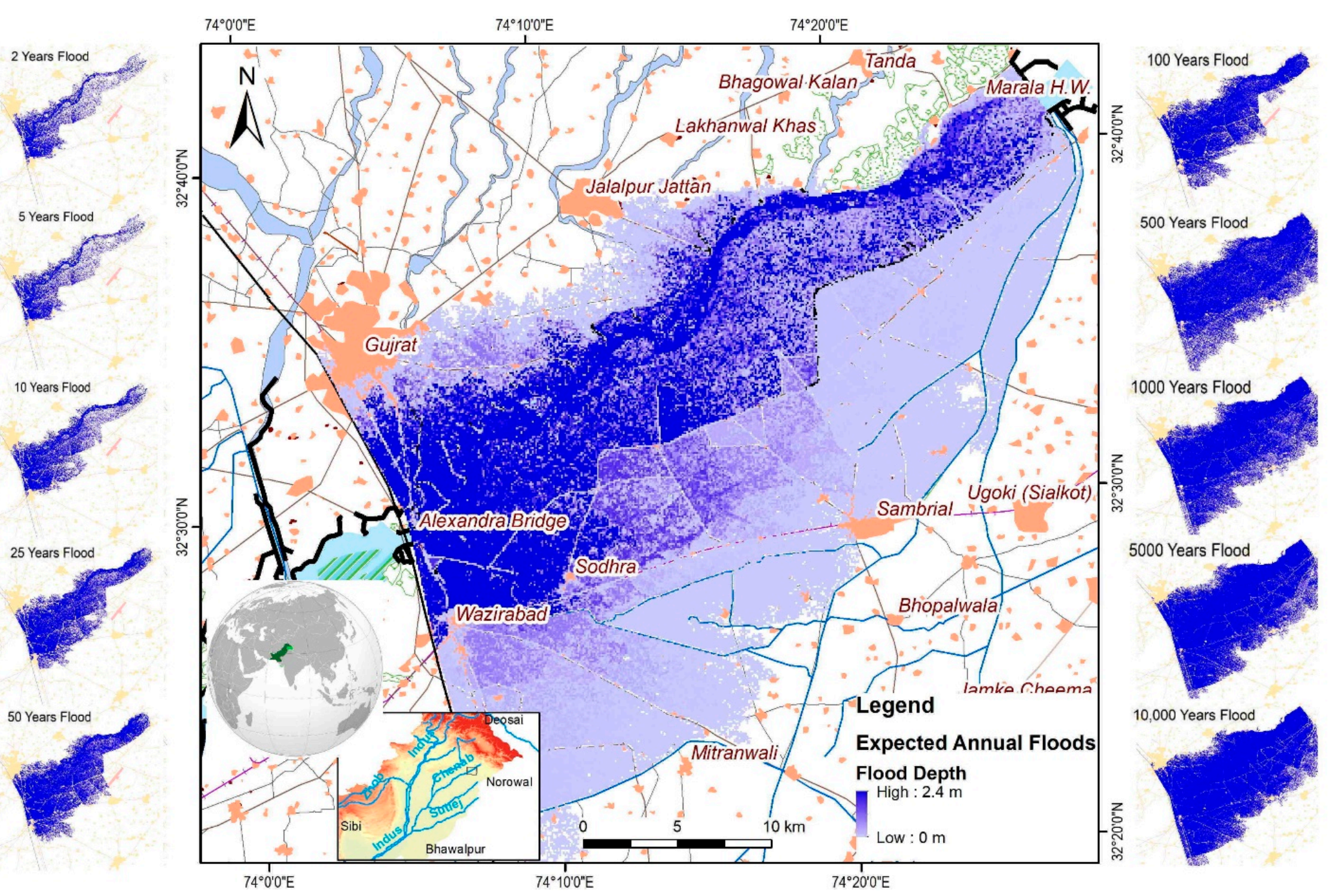

Figure 6. Hazard/intensity maps of the study area with flooding scenario on left and right sides (used for the risk calculations), whereas the central map is showing weighted overlaid flood spreads of different return periods based on their probability of occurrence for a visualization (not used in the calculation). 
The stage-damage functions are based on available historical data by local authorities and insurance companies, or are alternatively generated through laboratory experiments [23]. Due to the lack of accurate information available on historical flooding, estimations are usually accompanied by large margins [69]. In our case, suitable damage functions were developed through literature reviews and past projects. Our leading sources are local experts, Chen 1999 [70], Wang and Xiang [71], and the ANFAS project (Data Fusion for Flood Analysis and Decision Support) [72].

Figure 7 represents the stage-damage functions " $F_{a}(d)$ " used in our study. If " $D_{a, \max }$ " represents the maximum possible damage for a specific land-use " $a$ ", then the damage " $D_{a, i}$ " against a flood probability " $i$ " is estimated using Equation (6).

$$
D_{a, i}=F_{a}(d) \times D_{a, \max }
$$

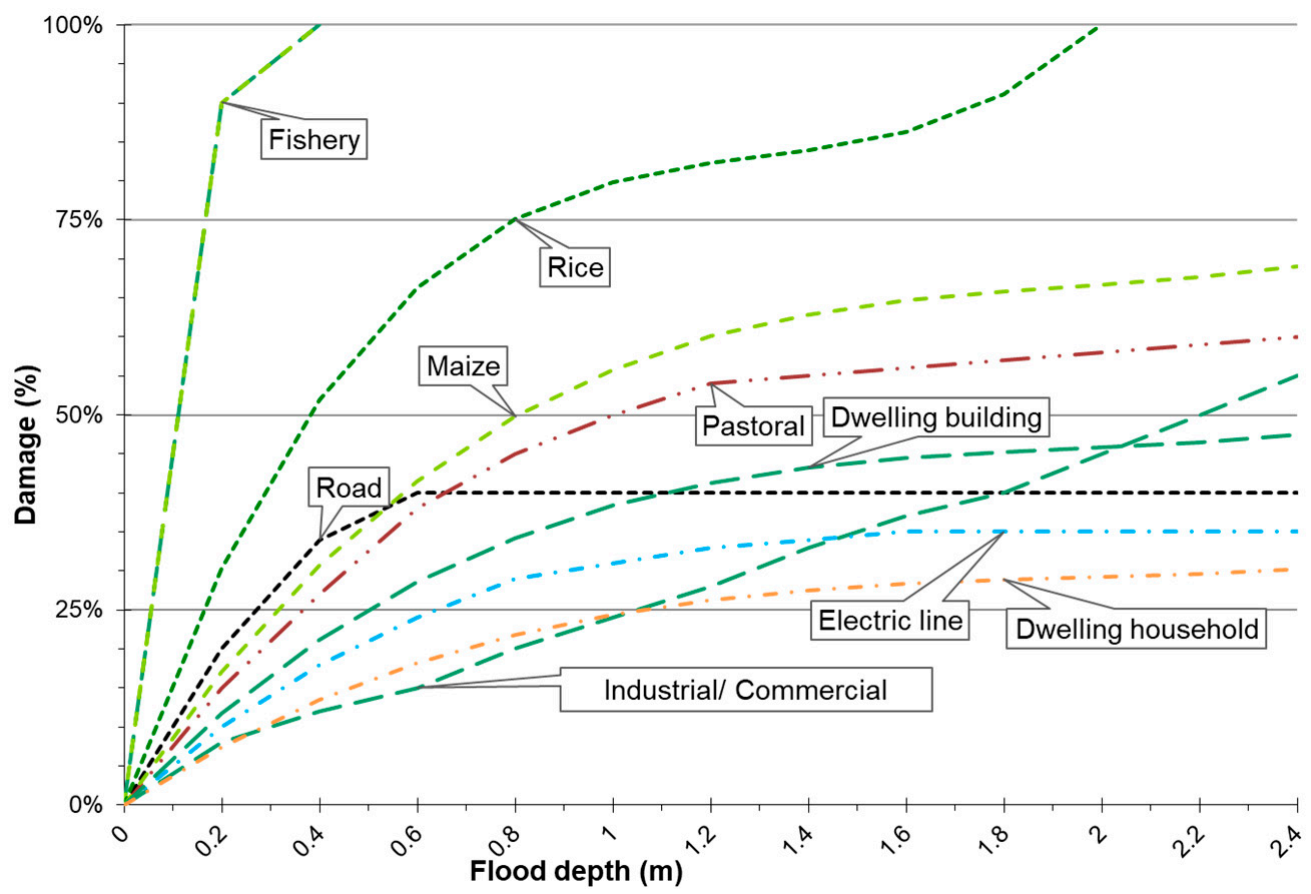

Figure 7. Stage-damage functions used for the study.

To facilitate the decision-makers, it is required to develop a common metric for all consequences of flooding, including tangibles and/or intangibles [14]. Except for the estimation of direct losses, a simple, accurate, and standard method for estimating indirect and intangible losses is far from maturation [10,73]. For practical reasons, only the important damage groups are used, depending on their possible contribution to encumber the efforts [73].

\subsubsection{Flood-Damage Maps}

Flood-damage maps were developed against each flood episode mentioned in Sections 3.3.2 and 3.3.3. Flood-damage maps for initial risk visualization were built by multiplying flood depth at each pixel by the land use (exposure map) using the susceptibility functions for that particular land use. The ArcGIS software tool is used for this purpose. These damage maps represent the damage distribution against each flood and need to be converted into a single risk map. The further process is described in the following sections.

\subsubsection{Baseline Risk Map}

For the practical purpose, multiple flood incidents are modelled/simulated for an accurate estimation of flood damages with minimum acceptable probable increments $\Delta P_{i}$. Then, the damages against each probability interval $D_{i}$ are estimated. $E A D$ can be 
calculated by summing up all these damages after multiplying to incremental probabilities. Damages are calculated for each flood episode; therefore, the damage value should be taken as the average of two floods' damages $D_{P_{i-1}}$ and $D_{P_{i}}$, covering the probability interval.

$$
\begin{gathered}
E A D=\sum_{i=0}^{i=\infty} D_{i} \times \Delta P_{i} \\
D_{i}=\frac{D_{P_{i-1}}+D_{P_{i}}}{2}
\end{gathered}
$$

Expected annual damages for the baseline (no measure) and existing conditions (50 years' protection dike) are calculated for comparison purposes. A range of probable floods is simulated for both scenarios. The expected flood losses for Chenab River based on baseline and existing conditions are shown in Figures 8 and 9. The floodplain is flat terrain; therefore, existing dikes are proven to be an effective solution. The flood losses for existing conditions are low, due to the few segmental dike walls already constructed in the study area. There is a vast area between the dikes and the river, which causes significant damages despite the presence of dikes. As a result, the difference between the no-measure and existing conditions damage is not huge. In addition, the roads and railway lines also curtail the fluvial flood expansion in the area. With the occurrence of high floods (surcharges), these dikes stop the return of floodwater to the river and intensify the flood losses in the floodplain. This can be seen in the curve presented in Figure 10.

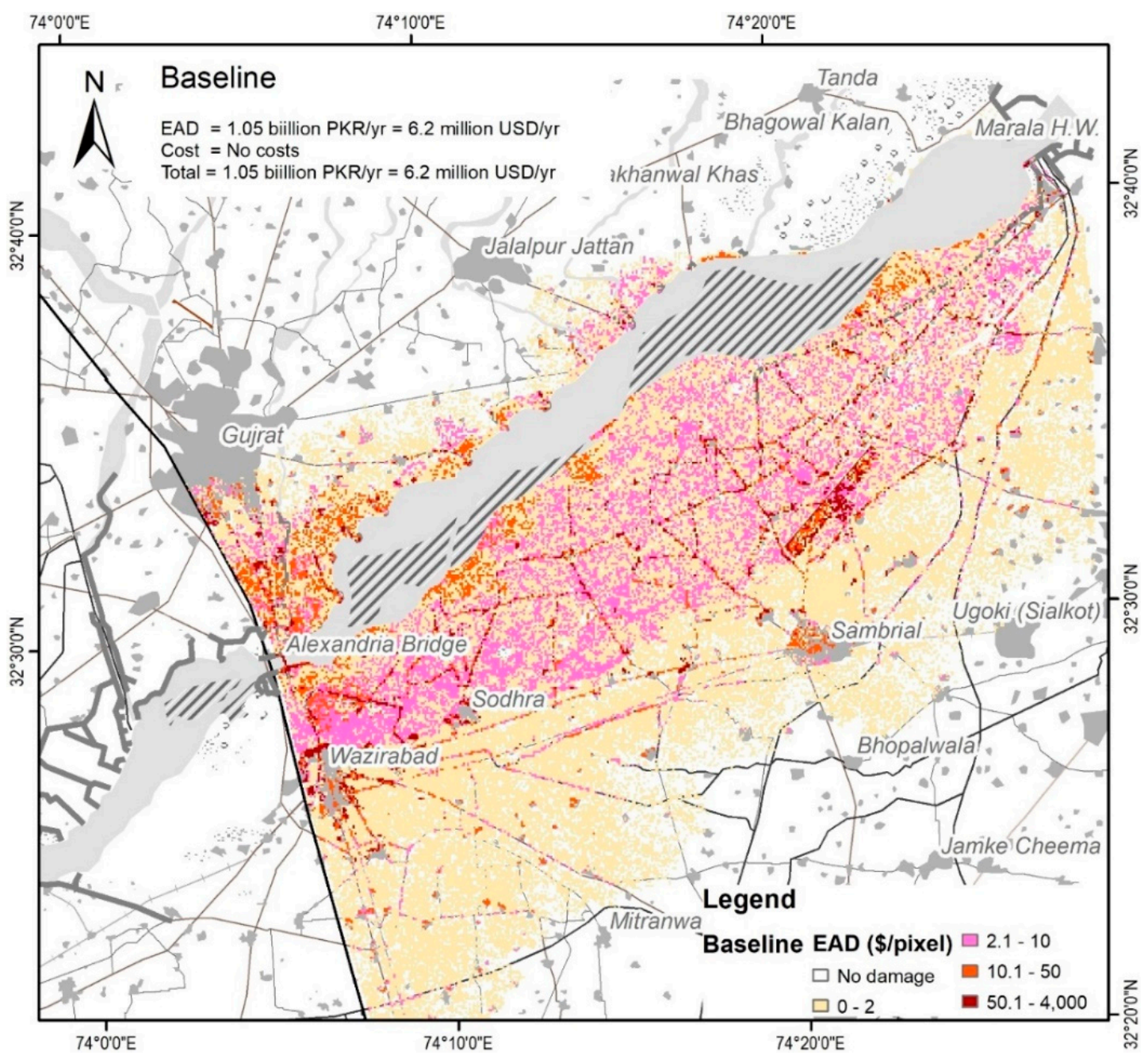

Figure 8. EAD distribution maps of baseline case showing the spatial distribution of EAD over the floodplain study reach. 


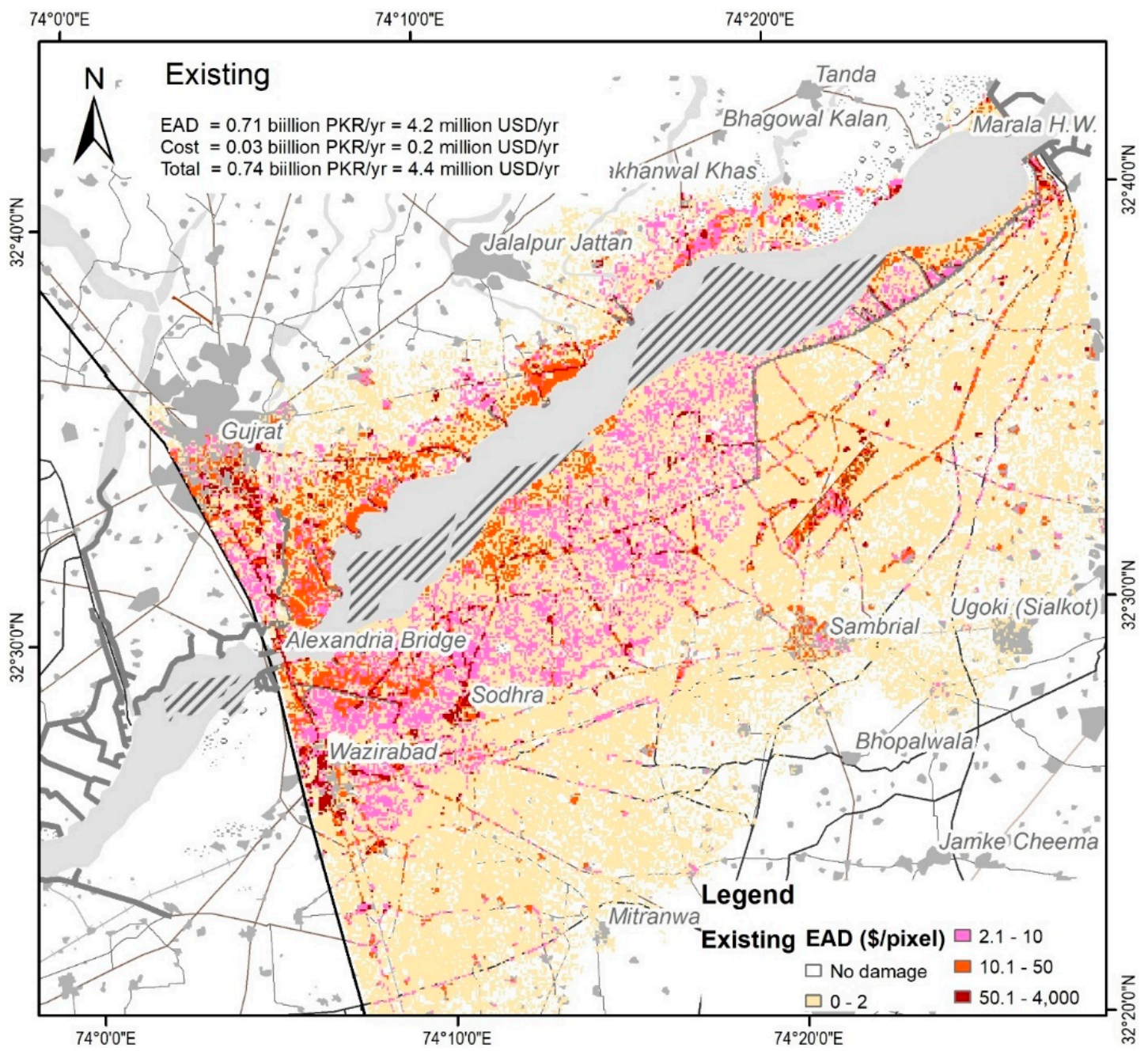

Figure 9. Spatial redistribution of risk over the floodplain study reach after the existing dikes are installed in the floodplain.

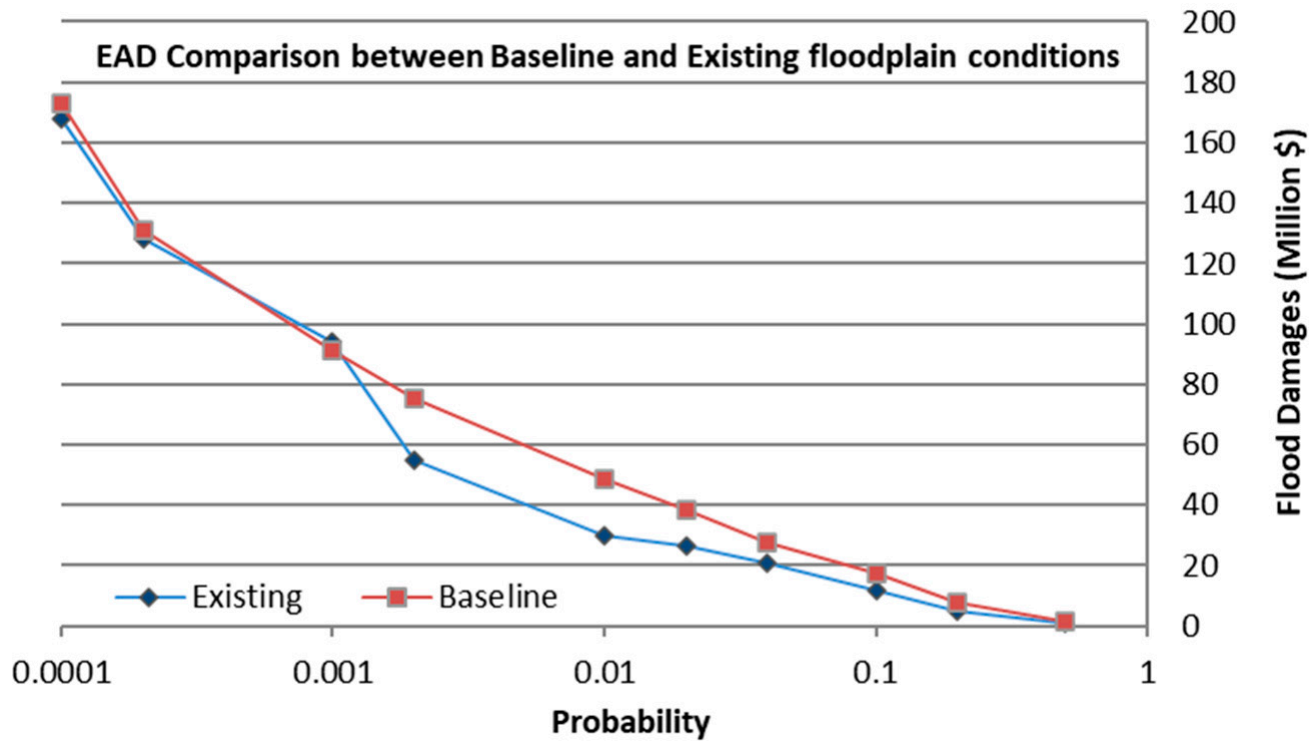

Figure 10. Damage curves for existing and baseline cases to show the trends in flood losses against floods in the Chenab River. 


\subsection{EAD Visualization}

The study compares the risk distribution when there is no flood mitigation measure with the existing situation. Therefore, it would be appropriate to have an overview of existing structural and nonstructural measures already in place.

\section{Existing Mitigation Measures}

The study area is flat and is prone to low velocities and longer flood durations. The depth of floodwater is anticipated as the intensity parameter for loss calculation. It is observed that the annual floodplain extent in the study area is about $10 \mathrm{~km}$ wide, and the same extends further, up to $25 \mathrm{~km}$, downstream due to the flat nature of the floodplain. The floodplain is very fertile land and is famous for the world's top-quality rice (Basmati rice) [74].

The study area is protected by earthen dikes mostly on the southern side of the river due to overall land slop. A large segment of earthen dike $(24.8 \mathrm{~km})$ protects the Marala-Ravi Link Canal, Upper Chenab Canal, and Sialkot International Airport. The protection design is a 50-year return period [75]. Small segments of river training works exist on the northern side just to protect or to reduce the impact of flood waves to the vital features.

A flood early warning system developed by Deltares is in place [75], which is under constant improvements. However, due to the location of study area, flood-protection dikes are the main measures supplemented by rescue and recovery operations carried out by the army.

\subsection{Existing Damage and EAD Maps}

Flood damages for the existing conditions were estimated considering the existing mitigation measures, following the same process as described in Sections 3.3.5 and 3.3.6 to develop the existing EAD maps. The overall reduction in damages over the floodplain with the current dikes can be seen in Figure 9.

\subsubsection{Residual Risk Indication}

Upstream of the Alexandria Bridge, there is more spread of flood for both scenarios due to the backwater effect (refer to Figures 8 and 9). A reason for this is that the upstream land level is steep towards the right bank. Additionally, the exiting dikes converge, and the cross section of the river is too narrow at the bridge. At this location, there are two important cities, Gujrat on the right, and Wazirabad towards the south side. Another highly exposed area is the Sialkot International Airport.

It is obvious that the risk moved from upstream to downstream after the existing dikes were introduced to the floodplain. The baseline case demonstrates higher risk upstream, while the downstream risk is higher for the existing conditions towards the Alexandria Bridge and cities of Gujrat and Wazirabad. At the same time, the risk shift to the right bank after the dikes were in place is clearly observable in Figures 8 and 9.

In both scenarios, the limited design flow capacity of Alexandria Bridge, which is $20,135 \mathrm{~m}^{3} / \mathrm{s}$, is inducing a backwater effect and the higher floods are causing more submergence of the floodplain just upstream of the bridge. This phenomenon is more noticeable in existing conditions, as the dikes reduce the channel storage capacity and route a higher flood peak. To reduce the flooding extents just upstream of the Alexandria Bridge, the dikes should be separated a bit farther from the river to attenuate the peak discharge during flood routing, or, alternatively, the design flow capacity of Alexandria Bridge should be increased.

\subsubsection{Existing EAD Charts}

Existing dikes reduced the flood damages by USD 2 million from USD 6.2 million to USD 4.2 million by spending USD 0.2 million on a yearly basis, including the capital and maintenance costs over the service lifespan. The benefit-cost ratio appeared to be 10, which is appreciable. Figure 10 shows the total damages against each probable flood considered 
for baseline and existing cases. It can be observed that the main reduction in damages is observable for 50-, 100-, and 500-year return periods. The reduction at the 500-year return period is mere because of the design safety margin and provision of freeboard in the dike design. However, somewhat similar damages can be observed for higher floods.

\section{Conclusions and Recommendations}

For the development of each EAD map, multiple hydrodynamic simulations were carried out to investigate the behaviour of all probable floods in the floodplain. Risk calculations also involved the incremental probabilities to estimate the risk increments for the range of probable floods. The methodology adopted in this research has some salient features that exhibit additional advantages over the conventional approaches of flood-risk maps being practiced nowadays:

1. A generalized approach was developed for a risk-based flood-management approach for the design of structural measures.

2. The EAD maps were developed considering a range of possible flood events with a range of probabilities. These maps considered the marginal increase in loss against the incremental probability of the event to ensure that risk thus calculated counts the probable nature of flood losses.

3. These maps not only provide the initial distribution of risk in a floodplain but also are able to envisage the redistribution of risk after a flood management measure is implemented.

4. The proposed method is based on the philosophy to consider all floods and all scenarios (pre- and post-measure); therefore, these maps have the capability to envisage the potential risks in a floodplain even after a measure is applied.

5. These maps also have the capability to design nonstructural measures (although not covered in this study).

The results demonstrate that EAD maps offer a detailed density distribution of damages over a floodplain, which is an advantage as it helps to point out the highly vulnerable spots. The results of these damage maps will be useful for flood management, as they can express the damages in terms of risk, with the probability connected to damages. It can also be concluded that the induced flood risk should be considered and appropriately modelled to include a cost-benefit analysis covering all such impacts.

The dikes proved to be economic measures to help in reducing flood damages due to the topography of the floodplain and exposure (dominantly urban land use) within the study reach. As proposed in the defined framework shown in Figure 2, secondary mitigation measures can be shortlisted for further analysis. For example, the locations with high losses may be treated with flood zoning and dikes may be made higher at these locations. Localized ring dikes (flood-proofing) may also be provided to reduce part of the losses. However, the damages might be still high, as indirect losses are high for some facilities such as the airport in our study area. Providing dikes with more space for high flows may result in reduced losses. As a generalized conclusion, dikes reduce overall flood losses but also increase flood losses by blocking the return of floodwaters.

Although risk-based designs are characterized by their ability to account for the residual/induced risks, the involvement of GIS enhances their capabilities by handling induced risk during the design process. Estimation of residual risk helps in the planning of structure-failure situations. It is fair to say that the involvement of GIS data not only enhances reliability and provides more information, but also saves time in the design of flood measures.

Floodwater depths were used for the calculation of flood damages in intensity-damage functions. More accurate results are expected if the flood simulation also considers the submergence time for the damage calculations, as the dikes significantly prolong the floodwaters to keep the floodplain submerged. In addition, dike failure can be a simulation for surcharge flows to increase the accuracy of results. 
Author Contributions: Conceptualization, M.A.U.R.T. and S.J.; Data curation, M.A.U.R.T.; Formal analysis, M.A.U.R.T. and R.F.; Investigation, M.A.U.R.T. and M.L.U.R.S.; Methodology, M.A.U.R.T. and A.W.M.N.; Project administration, M.A.U.R.T.; Resources, M.A.U.R.T. and A.W.M.N.; Software, M.A.U.R.T. and M.I.S.; Visualization, M.A.U.R.T., M.H. and A.W.M.N.; Writing-original draft, M.A.U.R.T., N.M., Z.R. and M.H.; Writing-review \& editing, M.A.U.R.T., Z.R. All authors have read and agreed to the published version of the manuscript.

Funding: This research received no external funding.

Institutional Review Board Statement: Not applicable.

Informed Consent Statement: Not applicable.

Data Availability Statement: Not applicable.

Conflicts of Interest: The authors declare no conflict of interest.

\section{Appendix A}

Model parameter performance plots for Marala Headworks and Alexandria Bridge shown in Figures A1 and A2.

\section{Marala Headworks}

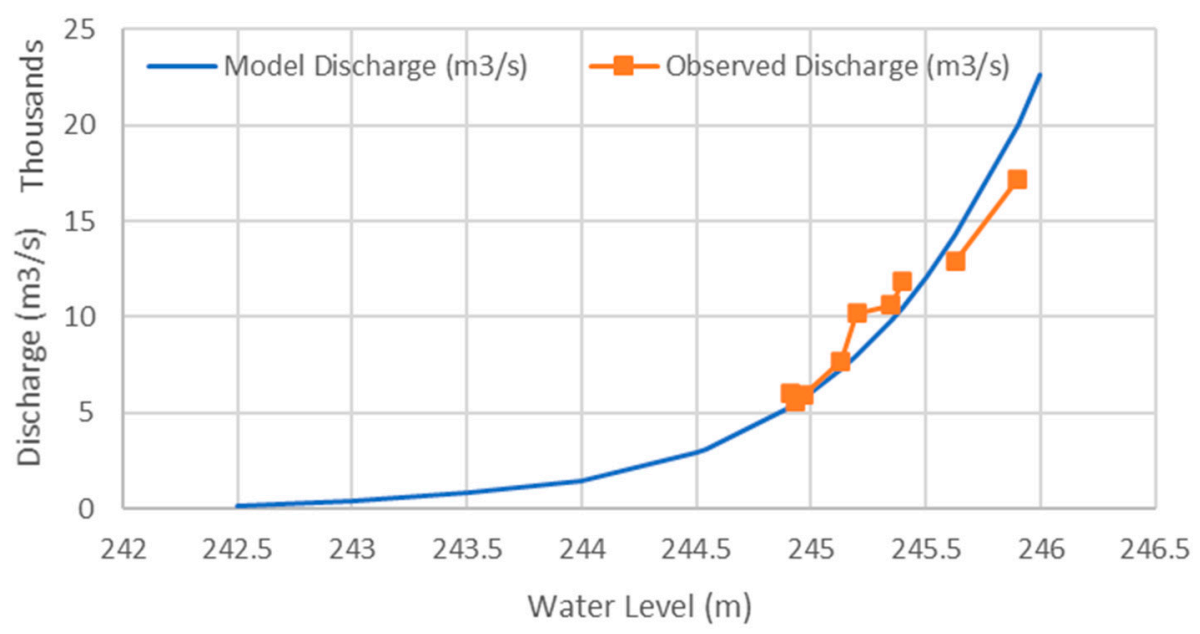

Figure A1. Model parameter performance plots for Marala Headworks.

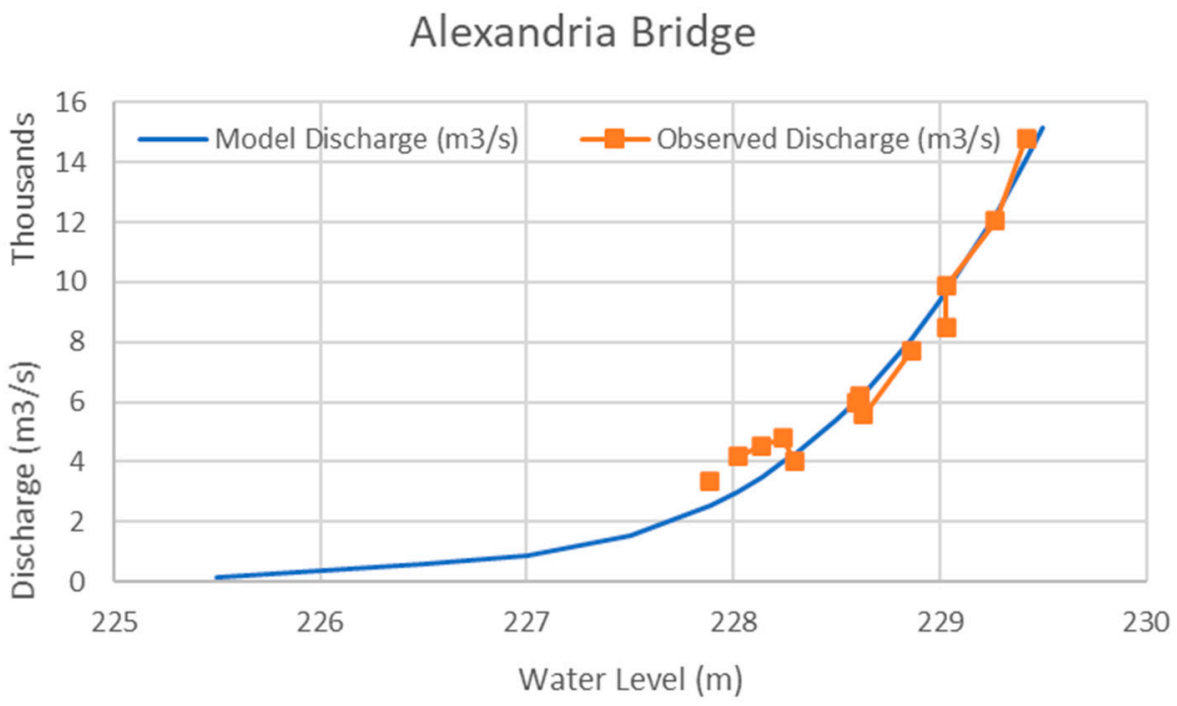

Figure A2. Model parameter performance plots for Alexandria Bridge. 


\section{References}

1. Van Duivendijk, J. Assessment of Flood Management Options. In Assessment of Flood Control and Management Options; World Commission on Dams: Cape Town, South Africa, 1999.

2. Pilon, P.J. Guidelines for Reducing Flood Losses; United Nations-Hqrs. (UN): New York, NY, USA, 2002. Available online: https / / www.unisdr.org/we/inform/publications/558 (accessed on 10 November 2021). [CrossRef]

3. Association of State Floodplain Managers; ASFPM; Ink, L.S. No Adverse Impact: A Toolkit for Common Sense Floodplain Management; Larson, L.A., Klitzke, M.J., Brown, D.A., Eds.; Association of State Floodplain Managers: Madison, WI, USA, 2003.

4. White, G.F.; Flood, N.; Forum, P. Reducing Flood Losses: Is the 1\% Chance (100-year) Flood Standard Sufficient? In Proceedings of the 2004 Assembly Gilbert F. White National Flood Policy Forum, Washington, DC, USA, 21-22 September 2004.

5. Collins, E.; Simpson, L. The impact of climate change on insuring flood risk. In Proceedings of the Biennial Convention, Institute of Actuaries of Australia, Christchurch, New Zealand, 23-26 September 2007.

6. Collins, E.; Simpson, L. Flood risk-The impact of climate change. Proc. Inst. Civ. Eng. Civ. Eng. 2002, 150, 22-24. [CrossRef]

7. Sikorska-Senoner, A.E.; Seibert, J. Flood-type trend analysis for alpine catchments. Hydrol. Sci. J. 2020, 65, 1281-1299. [CrossRef]

8. Borrows, P.; de Bruin, D. The management of riverine flood risk. Irrig. Drain. 2006, 55, S151-S157. [CrossRef]

9. Petry, B. Keynote lecture: Coping with floods: Complementarity of structural and non-structural measures. In Flood Defence; Science Press: New York, NY, USA, 2002; pp. 60-70.

10. White, G.F.; Kates, R.W.; Burton, I. Knowing better and losing even more: The use of knowledge in hazards management. Glob. Environ. Chang. Part B Environ. Hazards 2001, 3, 81-92. Available online: http:/ /www.sciencedirect.com/science/article/B6VPC44RNRCB-1/2/b6c636431e506950dce2076ce65cc368 (accessed on 16 November 2021). [CrossRef]

11. Hoes, O.; Schuurmans, W. Flood standards or risk analyses for polder management in the Netherlands. Irrig. Drain. 2006, 55, S113-S119. [CrossRef]

12. Andjelkovic, I. Guidelines on Non-Structural Measures in Urban Flood Management; UNESCO, International Hydrological Programme: Paris, France, 2001.

13. Nathwani, J.S.; Lind, N.C.; Pandey, M.D. Affordable Safety by Choice: The Life Quality Method; University of Waterloo: Waterloo, ON, Canada, 1997.

14. Schanze, J.; Zeman, E.; Marsalek, J. Flood Risk Management: Hazards, Vulnerability and Mitigation Measures; Springer: Berlin/Heidelberg, Germany, 2006.

15. Pistrika, A.K.; Tsakiris, G. Flood risk assessment: A methodological framework. In Proceedings of the Water Resources Management: New Approaches and Technologies, Chania, Crete, Greece, 14-16 June 2007.

16. WMO; APFM. Integrated Flood Management Concept Paper; World Meteorological Organization: Geneva, Switzerland, 2009 ; Volume 7.

17. Chetty, K.; Smithers, J. Continuous simulation modelling for design flood estimation in South Africa: Preliminary investigations in the Thukela catchment. Phys. Chem. Earth Parts A/B/C 2005, 30, 634-638. Available online: http:/ / www.sciencedirect.com/ science/article/pii/S1474706505000732 (accessed on 20 November 2021). [CrossRef]

18. Wobus, C.; Zheng, P.; Stein, J.; Lay, C.; Mahoney, H.; Lorie, M.; Mills, D.; Spies, R.; Szafranski, B.; Martinich, J. Projecting Changes in Expected Annual Damages from Riverine Flooding in the United States. Earths Futur. 2019, 7, 516-527. [CrossRef]

19. Diaconu, D.C.; Costache, R.; Popa, M.C. An Overview of Flood Risk Analysis Methods. Water 2021, 13, 474. [CrossRef]

20. Wagner, S.; Souvignet, M.; Walz, Y.; Balogun, K.; Komi, K.; Kreft, S.; Rhyner, J. When does risk become residual? A systematic review of research on flood risk management in West Africa. Reg. Environ. Chang. 2021, 21, 84. [CrossRef]

21. Alkema, D.; Middelkoop, H. The Influence of floodplain Compartmentalization on flood risk within the Rhine-Meuse Delta. In Flood Risk Management in Europe: Innovation in Policy and Practice; Begum, S., Stive, M.J.F., Hall, J.W., Eds.; Springer: Dordrecht, The Netherlands, 2007; pp. 21-42. ISBN 978-1-40120-4199-0.

22. WMO; Ministry_Zambia; APFM. Strategy for Flood Management for Kafue River Basin, Zambia; Associated Programme Flood Management; World Meteorological Organization: Geneva, Switzerland, 2007.

23. Genovese, E. A Methodological Approach to Land Use-Based Flood Damage Assessment in Urban Areas: Prague Case Study; Institute for Environment and Sustainability: Ispra, Italy, 2006.

24. De Salvo, M.; Capitello, R.; Gaudenzi, B.; Begalli, D. Risk management strategies and residual risk perception in the wine industry: A spatial analysis in Northeast Italy. Land Use Policy 2019, 83, 47-62. [CrossRef]

25. Li, C.; Cheng, X.; Li, N.; Du, X.; Yu, Q.; Kan, G. A Framework for Flood Risk Analysis and Benefit Assessment of Flood Control Measures in Urban Areas. Int. J. Environ. Res. Public Health Artic. 2016, 13, 787. [CrossRef] [PubMed]

26. Carter, N.T. Flood Risk Management: Federal Role in Infrastructure; Congressional Research Service: Washington, DC, USA, 2005.

27. Criss, R.E.; Shock, E.L. Flood enhancement through flood control. Geology 2001, 29, 875-878. [CrossRef]

28. Everard, M. Investing in sustainable catchments. Sci. Total Environ. 2004, 324, 1-24. [CrossRef]

29. Pinter, N.; Huthoff, F.; Dierauer, J.; Remo, J.W.F.; Damptz, A. Modeling residual flood risk behind levees, Upper Mississippi River, USA. Environ. Sci. Policy 2016, 58, 131-140. [CrossRef]

30. Majewski, W. New approach to flood management. Publ. Inst. Geophys. Polish Acad. Sci. Warszawa Pol. 2007, 401, 149-158.

31. Penning-Rowsell, E.C.; Green, C.H. Enhanced appraisal of flood alleviation benefits. In New Approaches and Lessons from Experience; Wiley: London, UK, 2000; Volume I, pp. 214-238. [CrossRef]

32. Carton, L. Strengths and Weaknesses of Spatial Language: Mapping Activities as Debating Instrument in a Spatial Planning Process; FIG XXII International Congress: Washington, DC, USA, 2002; p. 13. 
33. Tariq, M.A.U.R.; van de Giesen, N.; Hoes, O. Risk-based assessment of coalesced response of embankments and flood zoning, employing EAD: The Chenab River case study. J. Hydroinformatics 2013, 27, 1957-1966.

34. Tariq, M.A.U.R.; Hoes, O.A.C.; Van de Giesen, N.C. Development of a risk-based framework to integrate flood insurance. J. Flood Risk Manag. 2014, 7, 291-307. [CrossRef]

35. Tucci, C.E.M. Urban Flooding; The Federal Public Ministry (MPF): Porto Alegre, Brazil, 2002.

36. De Bruijn, K.M.; van Beek, E. Resilience and Flood Risk Management: A Systems Approach Applied to Lowland Rivers. Ph.D. Thesis, Technische Universiteit Delft, Delft, The Netherlands, 2005.

37. Di Baldassarre, G.; Laio, F.; Montanari, A. Design flood estimation using model selection criteria. Phys. Chem. Earth Parts A/B/C 2009, 34, 606-611. [CrossRef]

38. Tucci, C.E.M. Urban Flood Management; World Meteorological Organization: Porto Alegre, RS, Brazil, 2007.

39. Tucci, C.E.M.; Villanueva, A.O.N. Flood control measures in União da Vitoria and Porto União: Structural vs. non-structural measures. Urban Water 1999, 1, 177-182. [CrossRef]

40. Yoe, C. Framework for Estimating National Economic Development Benefits and Other Beneficial Effects of Flood Warning and Preparedness Systems; U.S. Army Corps of Engineers: Washington, DC, USA, 1994.

41. Olsen, A.S.; Zhou, Q.; Linde, J.J.; Arnbjerg-Nielsen, K. Comparing methods of calculating expected annual damage in urban pluvial flood risk assessments. Water 2015, 7, 255-270. [CrossRef]

42. Erdlenbruch, K.; Thoyer, S.; Grelot, F.; Kast, R.; Enjolras, G. Risk-sharing policies in the context of the French Flood Prevention Action Programmes. J. Environ. Manag. 2009, 91, 363-369. [CrossRef] [PubMed]

43. Purdy, G. ISO 31000:2009-Setting a New Standard for Risk Management. Risk Anal. 2010, 30, 881-886. [CrossRef] [PubMed]

44. Jonkman, S.N.; Bockarjova, M.; Kok, M.; Bernardini, P. Integrated hydrodynamic and economic modelling of flood damage in the Netherlands. Ecol. Econ. 2008, 66, 77-90. [CrossRef]

45. Vrijling, J.K. Probabilistic design of water defense systems in The Netherlands. Reliab. Eng. Syst. Saf. 2001, 74, 337-344. [CrossRef]

46. Tzioutzios, C.; Kastridis, A. Multi-Criteria Evaluation (MCE) Method for the Management of Woodland Plantations in Floodplain Areas. ISPRS Int. J. Geo-Inf. 2020, 9, 725. [CrossRef]

47. Addy, S.; Wilkinson, M.E. Representing natural and artificial in-channel large wood in numerical hydraulic and hydrological models. WIREs Water 2019, 6, e1389. [CrossRef]

48. Blanchard-Boehm, R.D.; Berry, K.A.; Showalter, P.S. Should flood insurance be mandatory? Insights in the wake of the 1997 New Year's Day flood in Reno Sparks, Nevada. Appl. Geogr. 2001, 21, 199-221. [CrossRef]

49. Li, Y.; Zhang, Z.; Gong, S.; Liu, M.; Zhao, Y. Risk assessment of rainstorm disasters under different return periods: A case study of Bohai Rim, China. Ocean Coast. Manag. 2020, 187, 105107. [CrossRef]

50. Tariq, M.A.U.R.; Farooq, R.; Giesen, N. van de A Critical Review of Flood Risk Management and the Selection of Suitable Measures. Appl. Sci. 2020, 10, 8752. [CrossRef]

51. Tariq, M.A.U.R.; Farooq, R.; Van De Giesen, N. Development of a Preliminary-Risk-Based Flood Management Approach to Address the Spatiotemporal Distribution of Risk under the Kaldor-Hicks Compensation Principle. Appl. Sci. 2020, $10,9045$. [CrossRef]

52. ADCP; UNDP. Integrated Flood Risk Management in Asia: A Primer; RMIT University: Melbourne, Australia, $2005 ;$ p. 332.

53. Messner, F.; Penning-Rowsell, E.; Green, C.; Tunstall, S.; Van Der Veen, A.; Tapsell, S.; Wilson, T.; Krywkow, J.; Logtmeijer, C.; Fernández-bilbao, A.; et al. Evaluating Flood Damages: Guidance and Recommendations on Principles and Methods; FLOODsite Consortium, European Union, Helmholz Unweltforschungszentrum (UFZ): Leipzig, Germany, 2007.

54. Apel, H.; Merz, B.; Thieken, A.H. Influence of dike breaches on flood frequency estimation. Comput. Geosci. 2009, 35, 907-923. [CrossRef]

55. Kron, W. Flood Risk = Hazard • Values • Vulnerability. Water Int. 2005, 30, 58-68. [CrossRef]

56. NESPak. Second Flood Protection Sector Project-Package C Strengthening Flood Forecasting, Management and Warning System; Federal Flood Commission of Pakistan: Islamabad, Pakistan, 2008; Volume 1.

57. Tariq, M.A.U.R.; van de Giesen, N.; Janjua, S.; Shahid, M.L.U.R.; Farooq, M.R. An Engineering Perspective of Water Sharing Issues in Pakistan. Water 2020, 12, 477. [CrossRef]

58. Landuyt, L.; Van Coillie, F.M.B.; Vogels, B.; Dewelde, J.; Verhoest, N.E.C. Towards Operational Flood Monitoring in Flanders Using Sentinel-1. IEEE J. Sel. Top. Appl. Earth Obs. Remote Sens. 2021, 14, 11004-11018. [CrossRef]

59. Ghasemigoudarzi, P.; Huang, W.; De Silva, O.; Yan, Q.; Power, D.T. Flash flood detection from CYGNSS data using the RUSBoost algorithm. IEEE Access 2020, 8, 171864-171881. [CrossRef]

60. Francés, F.; Botero, B.A. Flood frequency analysis for extreme events. In Advances in Urban Flood Management. Taylor E Francis/Balkema; Ashley, R., Garvin, S., Pasche, E., Vassilopoulos, A., Zevenbergen, C., Eds.; CRC Press: Boca Raton, FL, USA, 2007; pp. 123-138.

61. Ahmad, I. Design Flood. PC Based Hydraulic Design Packages. p. A Flood Hydrograph PC Based Package. 1994. Available online: https:/ / global.hauraton.com/en/hydraulic-design-software/ (accessed on 25 November 2021).

62. Lehner, B.; Verdin, K.; Jarvis, A. USGS HydroSHEDS; U.S. Geological Survey: Reston, VA, USA, 2008.

63. Deltares. SOBEK 1DFLOW (Rural)-Deltares 2021. Available online: https://www.deltares.nl/en/software/module/sobek1dflow-rural/ (accessed on 28 November 2021).

64. Te Chow, V.; Maidment, D.R.; Mays, L.W. Applied Hydrology; McGraw-Hill: New York, NY, USA, 1988. 
65. NESPak; Delft-Hydraulics. Floodplain and Flood Risk Mapping; Federal Flood Commission of Pakistan: Islamabad, Pakistan, 2008; Volume 1.

66. Yi, C.S.; Lee, J.H.; Shim, M.P. GIS-based distributed technique for assessing economic loss from flood damage: Pre-feasibility study for the Anyang Stream Basin in Korea. Nat. Hazards 2010, 55, 251-272. [CrossRef]

67. Smith, D.I. Flood damage estimation-A review of urban stage-damage curves and loss functions. Water SA 1994, $20,231-236$.

68. Middelmann-Fernandes, M.H. Flood damage estimation beyond stage-damage functions: An Australian example. J. Flood Risk Manag. 2010, 3, 88-96. [CrossRef]

69. Douben, K.-J. Characteristics of river floods and flooding: A global overview, 1985-2003. Irrig. Drain. 2006, 55, 9-21. [CrossRef]

70. Chen, Y.F. A New Weighted Function Moments Method to Estimate Parameters of P-III Distribution with Historical Floods; Hohai University Press: Nanjing, China, 1999.

71. Wang, Y.; Xiang, L. Study on flood damage assessment modes of different scales in China. In Flood Defence; Seience Press: New York, NY, USA, 2002.

72. ANFAS. Literature Review for a Socio-Economic Impacts Assessment Procedure for Qianliang Hu Detention Basin, Hunan Province, China, Yangtze River Flood Control and Management Project. 2003. Available online: https://d1rkab7tlqy5f1 .cloudfront.net/TBM/Over\%20faculteit/Afdelingen/Values\%2C\%20Technology\%20and\%20Innovation/People/Full\%20 Professors /Pieter\%20van\%20Gelder/Citations/citatie119.pdf (accessed on 9 December 2021).

73. Veerbeek, W. Flood induced indirect hazard loss estimation models. In Advances in Urban Flood Management. Taylor E Francis/Balkema; Ashley, R., Garvin, S., Pasche, E., Vassilopoulos, A., Zevenbergen, C., Eds.; CRC Press: Boca Raton, FL, USA, 2007 ; pp. 195-212.

74. Saleem, M.U.; Iqbal, N.; Iqbal, S.; Bin Khalid, U.; Iram, A.; Akhter, M.; Latif, T.; Awan, T.H. Reduced water use and labor cost and increased productivity of direct seeded basmati rice in Punjab, Pakistan. Sarhad J. Agric. 2020, 36, 603-611. [CrossRef]

75. Tariq, M.A.U.R.; van de Giesen, N. Floods and flood management in Pakistan. Phys. Chem. Earth Parts A/B/C 2012, 47-48, 11-20. [CrossRef] 